\author{
Jarosław ŚWIDA ${ }^{1}$ \\ Ewa KUBEJKO-POLAŃSKA ${ }^{2}$
}

\title{
OPPORTUNITIES FOR DEVELOPMENT OF ENTREPRENEURSHIP IN THE RANGE OF PRODUCT ADJUSTMENT TO THE NEEDS OF THE ELDERLY ${ }^{3}$
}

\begin{abstract}
The society ageing process forces the necessity to put attention to particular needs and expectations of the elderly consumers. It is necessary to identify the needs and expectations in the field of food product packaging. The distinguished needs constitute an opportunity for development of contemporary entrepreneurship by designing and offering innovative packaging which fulfil expectations of the elderly consumers. This article attempts to identify opportunities for entrepreneurship development in the silver economy area and in the range of adjusting food product packaging to the needs of the elderly consumers. The research was performed by means of CATI questionnaire interview method. The questionnaire consisted of two parts. Part one included questions concerning identification of needs and expectations of the elderly consumers in terms of food product packaging. Part two of the questionnaire were questions describing the respondents. The conducted research allowed to identify features of food product packaging which are important from the point of view of the elderly. Such consumer segment puts particular attention to certain benefits from packaging, such as a guarantee of safe product consumption, ease of product storage as well as provision of a necessary scope of information by the packaging. The research also shows that the elderly consumers prefer concrete features in the range of visual aspect of food product packaging. Therefore, actions aiming at persuading and attaching consumers to a given product by means of communication of packaging constitute a chance for the entrepreneurship.
\end{abstract}

Keywords: elderly consumers, silver economy, ageing population, food product packaging, consumer research.

\section{INTRODUCTION}

The basic challenge for the development of contemporary entrepreneurship is adjustment of an offer to fluctuating market demands. Identification of socio-economic determinants provides an opportunity for entrepreneurs to take proper actions aiming at optimisation of functioning of entities on the market. Among numerous endogenous and exogenous

\footnotetext{
${ }^{1}$ Jarosław Świda, Uniwersytet Ekonomiczny w Krakowie, Wydział Towaroznawstwa i Zarządzania Produktem, ul. Rakowicka 27, 31-510 Kraków; e-mail: swidaj@uek.krakow.pl

${ }^{2}$ Ewa Kubejko-Polańska, Uniwersytet Rzeszowski, Wydział Ekonomii, ul. Ćwiklińskiej 2, 35-601 Rzeszów; e-mail: ekubejko@ur.edu.pl

3 The article is funded by National Science Centre, Poland. The registration number of the project: 2014/13/B/HS4/00482
} 
determinants, the entrepreneurs should put particular attention to a society ageing process. Demographic transformations influence on functioning of business entities of production area, market and non-market services by occurrence of a new segment of the elderly consumers.

In connection with the above, entrepreneurship development strategies should include actions aiming at using the potential of the ageing society, according to the silver economy concept. A silver economy is defined as an economic system directed at using the potential of the elderly and taking their needs into consideration ${ }^{4}$. In Poland, implementation of various types of solutions included in the senior policy is helpful in realising assumptions of the silver economy concept. The Assumptions of Long-term Senior Policy, established in 2014 , define the major objective of senior policy in the area of the silver economy, i.e. support of development of effective solutions adjusted to the needs and expectations of the elderly ${ }^{5}$. In international terms, the features and directions of the silver economy development are defined by so-called Bonn Declaration. It was indicated in the document that active preparation of the economy for the new demographic proportions is an opportunity to improve the quality of life, economic growth and competitive Europe ${ }^{6}$. The silver economy development constitutes also one of assumptions of the report entitled Europe's demographic future issued by the European Commission ${ }^{7}$.

The silver economy concept originates from a research and scientific movement called gerontechnology, including numerous issues of interdisciplinary character, concerning technology and the ageing process, and its superior objective is to improve the daily life of the elderly ${ }^{8}$. According to S. Golinowska ${ }^{9}$, the concept of silver economy has two meanings. The first meaning consists in showing an economy evolving into the needs of the older population without its particular interventionist orientation. Another meaning indicates an opportunity to take advantage of the ageing society to such development orientation, in which the change of the structure of the needs and a certain increase in their activity could become a source of progress and economic growth. A social meaning of the concept consists in meeting the needs and aspirations of the ageing society. As far as the economic meaning is concerned, it consists in indicating benefits which result from establishing supply and demand factors. The supply factors include: longer work, higher qualifications, experience and life's stability. However, the demand factors represented by the elderly include purchasing power and consumption with a considerable potential for economic growth.

The basis of economic growth is development of enterprises in such key areas for the silver economy as time management of the elderly, caring for health and image, assuring social integration, providing appropriate financial services, assuring possibly the longest

${ }^{4}$ Silver Economy Network of European Regions: SEN@ER 2016 (www.silvereconomy-europe.org).

${ }^{5}$ Założenia Długofalowej Polityki Senioralnej w Polsce na lata 2014-2020, 2013, Monitor Polski Dziennik Urzędowy Rzeczypospolitej Polskiej, Warszawa.

${ }^{6}$ Bonn Declaration for the Silver Economy as an Opportunity for Quality of Life, Economic Growth and Competitiveness in Europe, 2005, www.silvereconomy-europe.org (02.09.2016).

${ }^{7}$ Europe's demographic future. Facts and figures on challenges and opportunities, 2007, European Commission, Luxembourg.

${ }^{8}$ J. Graafmans, V. Taipale, N. Charness, Gerontechnology. A sustainable investment in the future, IOS Press, Amsterdam 1998.

9 S. Golinowska, Srebrna gospodarka - element strategii rozwoju regionalnego [in:] Starzejace się społeczeństwo: nowe zadania dla polityk publicznych, Małopolskie Studia Regionalne nr 2-3/3132/2014, Kraków 2014. 
professional activity and possibly the longest self-reliance. Assuring possibly the longest self-reliance should consist both in providing appropriate services, e.g. cleaning, shopping, transport, which assist in a self-contained life, and products taking specific needs of the elderly into consideration ${ }^{10}$.

Dynamic growth of the number of the elderly consumers forces enterprises to continually search for new solutions allowing them to gain a competitive position on the market ${ }^{11}$. It is important to diversify the offer of market and non-market services so as to take full advantage of the potential of the silver economy in the regions ${ }^{12}$. M. Rembiasz ${ }^{13}$ emphasizes that the silver economy has a considerable developing potential for companies belonging to the SME sector because of their specific features such as an ability to react promptly on market needs, for example.

Pursuit of satisfying particular needs and expectations of the elderly consumers by offering new products to them. It, therefore, creates opportunities for development of entrepreneurship which determines the enterprise activity effectiveness. Since the entrepreneurship is not only continuation of the previous activity and improvement of management, decreasing costs, improving current financial results and risk reduction. It means, first of all, a response on changes in demand, conditions of competition, technological advance and institutional changes ${ }^{14}$. Signs of entrepreneurship constitute also taking actions which aim at meeting new challenges, threats as well as effective use of the new development opportunities which cause a necessity to constantly analyse of changes occurring in the environment $^{15}$.

In the consumption area, a level as well as consumption structure are significantly influenced by increased participation of the elderly and their economic emancipation ${ }^{16}$. The elderly are regarded as attractive customers by business entities. This group is increasing in numbers and has considerable purchasing power and permanent purchasing preferences (high brand and product loyalty ${ }^{17}$. Growing expectations of the elderly, who are increasingly aware in the range of gaining customised products at their disposal, are the major factor shaping the demand for goods and services. An efficient reaching the elderly consumers with a product offer requires familiarization with their specific needs, motivation, lifestyle, as well as understanding their way of thinking, what they are guided by when

${ }^{10}$ P. Szukalski, Trzy kolory: srebrny. Co to takiego silver economy?, „Polityka Społeczna” 2012, nr 5-6.

11 J. Szymczak, M. Ankiel-Homa, Opakowanie jednostkowe w działaniach marketingowych przedsiębiorstw, Poznań 2007.

${ }^{12}$ E. Kubejko-Polańska, The role of local self-government in stimulating urban development in the context of the construction of age-friendly cities and the concept of Silver Economy, Nierówności Społeczne a Wzrost Gospodarczy, 2017, nr 49 (1/2017).

${ }_{13}$ M. Rembiasz, Srebrna gospodarka szansa rozwoju MSP, Zeszyty Naukowe Uniwersytetu Szczecińskiego Nr 848, Ekonomiczne Problemy Usług nr 116, Szczecin 2015.

14 J.W. Bossak, Konkurencja i wspótpraca międzynarodowa, Warszawa 2013.

${ }^{15}$ B. Glinka, S. Gudkova, Przedsiębiorczość, Warszawa 2011.

${ }_{16}$ T. Zalega, Zachowania konsumenckie osób starszych w Polsce, „Handel Wewnętrzny” nr 2, 2016.

17 S. Golinowska, Srebrna gospodarka - element strategii rozwoju regionalnego [in:] Starzejące się społeczeństwo: nowe zadania dla polityk publicznych, Małopolskie Studia Regionalne nr 2-3/3132/2014, Kraków 2014. 
buying a given product, what they are afraid of and what they expect from an offerer, as well as how they should be communicated with ${ }^{18}$.

The specificity of older people as consumers is primarily due to various signs of aging. Ageing is perceived as a biological phenomenon connected to proceeding infirming of a body. People age in different biological ways; they experience different changes in physiological systems, such as, for example sight and hearing worsening or manual skills ${ }^{19}$. The consequence of the aging process is the perspective of living with the smaller opportunities that are necessary to deal with the growing environmental requirements.

One of the most important areas of active participation of the elderly on the market is an opportunity to satisfy the basic needs autonomously. It is determined by simplicity of using the basic goods and services, including food products, among others. It chiefly determines functionality, safety and comprehensibility of packaging, the assurance if which is a challenge and an opportunity of building a competitive advantage of enterprises at the same time, in the context of the growing number of older consumers.

The objective of the article is to determine an opportunity of developing entrepreneurship in the silver economy area and in the range of adjusting food product packaging to the needs of the elderly consumers.

Undertaking entrepreneurial actions in terms of adjusting packaging of food products to specific needs of the elderly consumers requires performing research in this range.

Currently, research is being systematically performed concerning determinants of a market packaging and packaged products as well as an impact of packaging on behaviour of consumers during shopping and the influence of the packaging on product satisfaction ${ }^{20}$. The research include all entities making a chain of packaging but becoming acquainted with needs, requirements and expectations of the elderly consumers as regards packaging may constitute an important suggestion for entrepreneurs offering food products on the market.

From the point of view of determining chances for development of entrepreneurship in terms of adjusting food product packaging to specific requirements of the elderly consumers, the range of research conducted by the authors of the article included: determination of importance of features and elements of food product packaging for the elderly consumers and their influence on the product selection, identification of the most important benefits from packaging and determination of preferences in the range of their visual part.

\section{RESEARCH METHODOLOGY}

The study was conducted in the period of November-December 2015 on a group of 600 consumers aged 60 and more, inhabiting an area of Małopolskie region. The sampling was of a quote character and it was depicted as follows: (table 1).

\footnotetext{
18 J. Świda, An elderly consumer as a specific research object of the marketing research, M. Gębarowski, T. Hermaniuk (ed.), Food Product Marketing. Concepts and Research, University of Maribor, Slovenia 2015.

${ }^{19}$ M. Mossakowska, A. Więcek, P. Błędowski, Aspekty medyczne, psychologiczne, socjologiczne i ekonomiczne starzenia się ludzi w Polsce, Poznań 2012.

${ }^{20}$ B. Kabaja, Możliwości wykorzystania metody TVScore do oceny znakowania opakowań na przykładzie suplementów diety, Zeszyty Naukowe UEK 8(956), Kraków 2016; M. Lisińska-Kuśnierz, Food packaging as non-satisfactory comunication instrument in opinion of consumers [in:] Innovations in product development and packaging, UEK, Kraków 2016.
} 
Table 1. Population of the researched respondents

\begin{tabular}{|c|c|c|c|c|c|c|c|c|}
\hline & \multicolumn{2}{|c|}{ Country } & \multicolumn{2}{c|}{$\begin{array}{c}\text { Town with up to 20 } \\
\text { thousand inhab. }\end{array}$} & $\begin{array}{c}\text { City with 20-200 } \\
\text { thousand inhab. }\end{array}$ & \multicolumn{2}{c|}{ Cracow } \\
\hline & $\mathrm{W}$ & $\mathrm{M}$ & $\mathrm{W}$ & $\mathrm{M}$ & $\mathrm{W}$ & $\mathrm{M}$ & $\mathrm{W}$ & $\mathrm{M}$ \\
\hline $\mathbf{6 0 - 6 9}$ & 75 & 64 & 20 & 16 & 32 & 25 & 47 & 35 \\
\hline $\mathbf{7 0 - 7 9}$ & 48 & 32 & 12 & 8 & 18 & 12 & 28 & 18 \\
\hline $\begin{array}{c}\mathbf{8 0} \text { and } \\
\text { more }\end{array}$ & 35 & 16 & 8 & 3 & 12 & 5 & 21 & 10 \\
\hline Total & \multicolumn{2}{|c|}{270} & \multicolumn{2}{|c|}{67} & \multicolumn{2}{c|}{104} & \multicolumn{2}{c|}{159} \\
\hline
\end{tabular}

Source: author's own study.

The majority of respondents $(59,3 \%)$ were women. The remaining number $(40,7 \%)$ were men.

The research was performed by means of CATI questionnaire interview method. The questionnaire consisted of two parts. Part one included questions concerning identification of needs and expectations of the elderly consumers in terms of food product packaging. Part two of the questionnaire were questions describing the respondents.

\section{RESULTS OF THE RESEARCH AND DISCUSSION}

Familiarization with importance of features of packaging of the food products may constitute an important suggestion in taking efficient actions concerning adjustment of a food product offer to the needs of the elderly consumers in making a decision on the purchase.

The analysis of the data from the source literature constituted a foundation for selection of features of food products which are essential from the point of view of the elderly consumers. On the basis of the results of the research performed by Hoyer, MacInnis ${ }^{21}$, Swida ${ }^{22}$, Yap \& Yazdanifard ${ }^{23}$ significant features from the point of view of the following functions performed by packaging, i.e. security, utility and communication ${ }^{24}$, were selected.

The study results concerning the importance of the researched packaging features of food products influencing on a decision about the purchase are presented in figure 1.

When defining the importance of packaging features influencing on the choice of a food product in 5-grade scale, the 'definitely important' and 'rather important' option was most frequently selected in case of such features as packaging safety $(53,2 \%$ and $38 \%$ respectively), easy storage $(29,2 \%$ and $63,0 \%)$ as well as greenness, i.e. environmental friendliness $(45,3 \%$ and $46,8 \%)$. Manufacturing quality, understood as the lack of packaging defect (30,5\% and $59,2 \%$ respectively) and information (39,5\% and $47 \%$ ) were frequently regarded as important. On the other hand, the shape turned out to be the least significant. the

${ }^{21}$ W.D. Hoyer, D.J. MacInnis, Consumer behavior, Australia: South-Western Cengage Learning 2010.

22 J. Świda, Zachowania rynkowe starszych konsumentów z punktu widzenia projektowania warstwy wizualnej opakowań, Zeszyty Naukowe UEK (918), Kraków 2013.

${ }^{23}$ C.W. Yap, R. Yazdanifard, How Consumer Decision Making Process Differ From Youngster to Older Consumer Generation, "Journal of Research in Marketing" 2014, 2(2).

${ }^{24}$ H.E. Lockhart, A Paradigm for Packaging, Packaging Technology and Science, 1997, 10(5). 
option 'very important' was selected by $7,2 \%$ of respondents, while a 'rather important' option was chosen by $27,8 \%$ of the total amount of the interviewees.

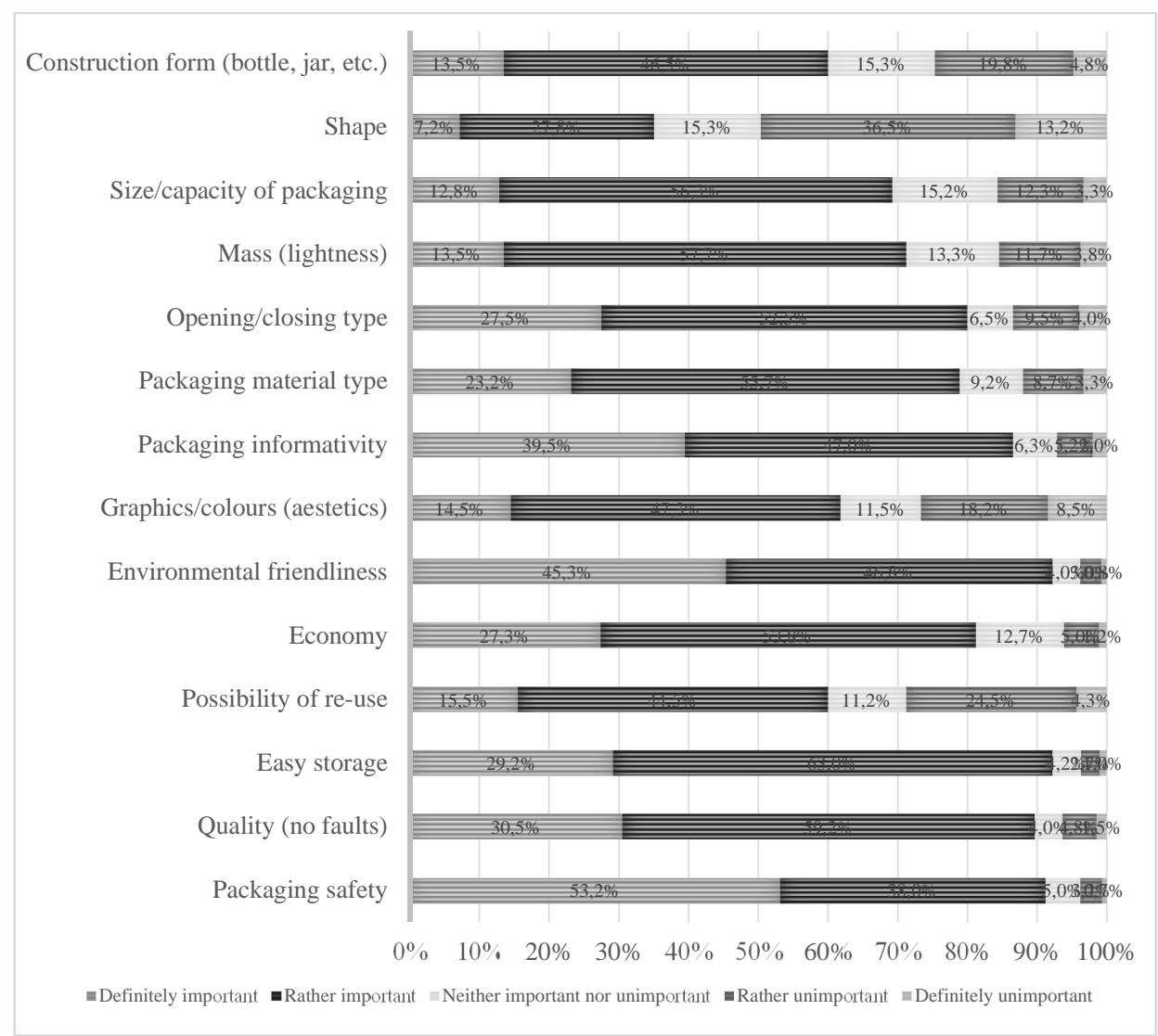

Figure 1. Importance of packaging features influencing on the food product selection

Source: J. Świda, A. Cholewa-Wójcik, A. Kawecka, Determinants of Creating Packaging Innovations for Older Consumers, Proceedings of The International Business Conference 2016: Searching for Innovative and Creative Business Solutions, Vilniaus Kolegija/University of Applied Sciences, Vilnius - Lithuania 2017.

An efficient reaching the segment of the elderly consumers with a market offer for products is also connected with conducting marketing activities by the entrepreneurs, and results of the research concerning the familiarization of the most important benefits from packaging and preferences in the range of visual part of the food product packaging may constitute a significant source of knowledge so as to determine the activities.

The results of responses for the question about indicating three most important benefits from food product packaging were presented in table 2 and in figure 2. 
Table 2. The number and percentage of selections in response of the question about three most important benefits from food product packaging

\begin{tabular}{|l|c|c|}
\hline \multicolumn{1}{|c|}{ Benefit } & Number of selections & \% of selections \\
\hline Guarantee safety of product consumption & 500 & $83,3 \%$ \\
\hline Enable to store a product easily & 417 & $69,5 \%$ \\
\hline Enable to move a product easily & 196 & $32,7 \%$ \\
\hline Include necessary range of information & 324 & $54,0 \%$ \\
\hline Educate consumers & 24 & $4,0 \%$ \\
\hline Encourage to the purchase & 38 & $6,3 \%$ \\
\hline Allow for easy identification of a product & 85 & $14,2 \%$ \\
\hline Arouse positive emotions and feelings & 22 & $3,7 \%$ \\
\hline Reflect the product quality & 57 & $9,5 \%$ \\
\hline Can be used for different purposes & 137 & $22,8 \%$ \\
\hline
\end{tabular}

Source: author's own study.

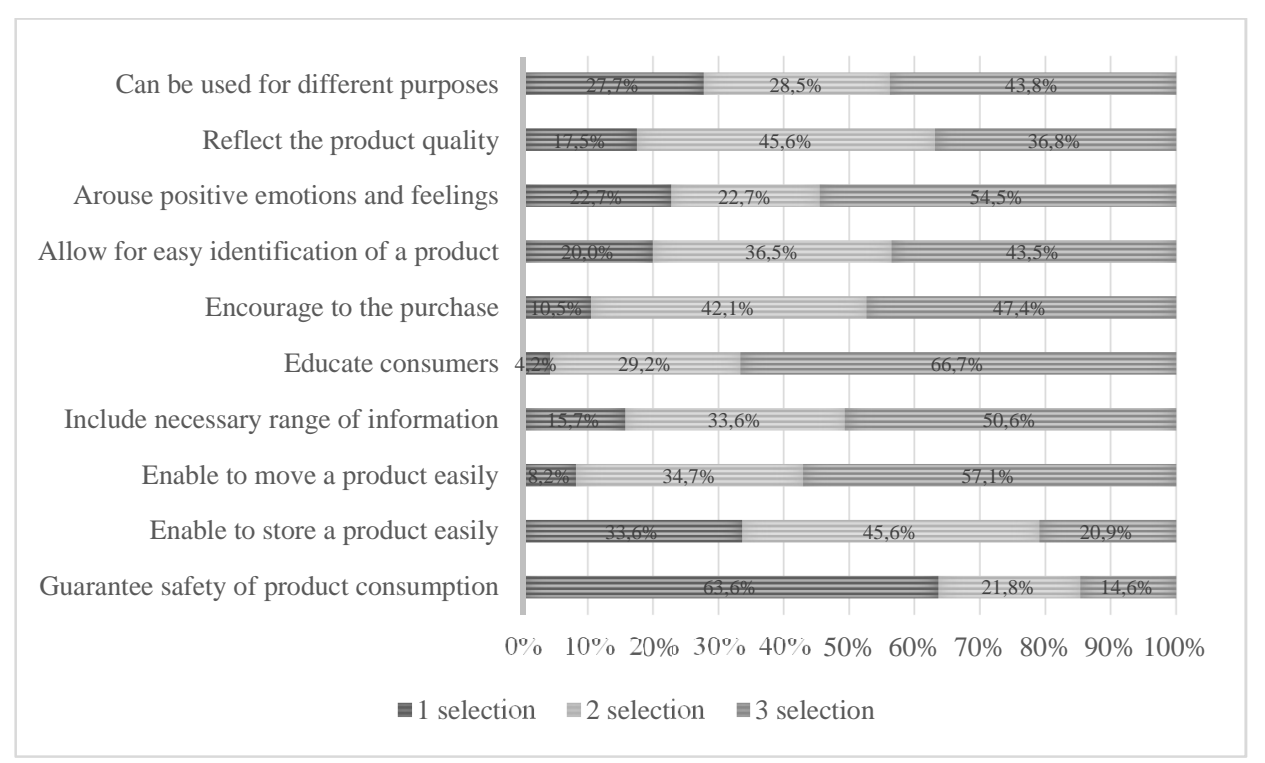

Figure 2. Distribution of replies to the question about three most important benefits from food product packaging

Source: author's own study.

In case of the question concerning the most important benefits from food product packaging, a frequency analysis was provided for each reply from the cafeteria indicated for a given item. In 500 cases it was regarded that the fact that packaging guarantee safety of product consumption is one of the three most important benefits of food product packaging 
(table 2). Moreover, in 63,6\% of such cases, this feature was selected on the first place (figure 2). An extremely important benefit for the elderly consumers turned out also to be product storage comfort (417 of selections), however, such benefit was most frequently indicated on the second place (45,6\% of cases), and providing a necessary range of information by the packaging ( 324 selections in the majority in the third place - 50,6\%). Significant benefits for the elderly consumers turned out to be also moving comfort and an opportunity of using packaging for different purposes (196 and 137 of selections respectively). The least frequently indicated benefits from the packaging turned out to be the following: arousing positive emotions by packaging and educating the elderly consumers (22 and 24 of selections respectively).

An average of the values ascribed to the responses, depending on the selection order, was calculated as summary of an analysis of selections of responses to the question about three most important benefits concerning food product packaging.

Table 3. Value of the average for particular benefits from food products

\begin{tabular}{|l|l|}
\hline Benefit & Average \\
\hline Guarantee safety of product consumption & 2.075 \\
\hline Enable to store a product easily & 1.478 \\
\hline Include necessary range of information & 0.892 \\
\hline Enable to move a product easily & 0.493 \\
\hline Can be used for different purposes & 0.420 \\
\hline Allow for easy identification of a product & 0.250 \\
\hline Reflect the product quality & 0.172 \\
\hline Encourage to the purchase & 0.103 \\
\hline Arouse positive emotions and feelings & 0.062 \\
\hline Educate consumers & 0.055 \\
\hline
\end{tabular}

Source: author's own study.

In case of each respondent the point value 3 was ascribed to the response selected on the first place, two points were ascribed to the response selected on the second place, and the response placed on the third place was given one point. The value 0 was attributed to the remaining responses, which were not counted towards the three most important ones by a respondent. Then, an arithmetic mean of the ascribed values was calculated for each option from the cafeteria. The value of the average is contained in the range from 0 to 3 . When the value set is close to the bottom limit of the range, it means that a given response was indicated by relatively few respondents. Otherwise, i.e. when the calculated average amounted to the value near 3, it means that a large percentage of interviewees selected a given response and, what is more, a large part of the respondents selected this response on the first place (table 3 ).

In the next part of the analysis of results of the performed research, preferences of the elderly in the range of selected elements of visual layer (table 4) were established. 
Table 4. Preferences of the elderly consumers in the range of selected elements of visual layer of food product packaging

\begin{tabular}{|l|l|c|l|c|}
\hline $\begin{array}{c}\text { An element of the } \\
\text { visual layer }\end{array}$ & $\begin{array}{c}\text { \% of } \\
\text { selections }\end{array}$ & & $\begin{array}{c}\text { \% of } \\
\text { selections }\end{array}$ \\
\hline Colours & Bright, intense & 15.5 & Pastel, sober & 84.5 \\
\hline Graphics & Modern, futuristic & 20.5 & Traditional, retro & 79.5 \\
\hline Packaging material & Chalk overlay, glossy & 12.5 & Matt, porous & 87.5 \\
\hline Fond type & Simple, angular, bold & 92.5 & $\begin{array}{l}\text { Round, slanted, } \\
\text { undulant }\end{array}$ & 7.5 \\
\hline Shape & Modern, original & 13.2 & $\begin{array}{l}\text { Plain, simple, } \\
\text { comfortable }\end{array}$ & 86.8 \\
\hline Type of closure & $\begin{array}{l}\text { Modern, safe, compli- } \\
\text { cated }\end{array}$ & 22.7 & Traditional, easy & 77.3 \\
\hline
\end{tabular}

Source: author's own study.

As the performed research indicates, the elderly consumers in the majority prefer the packaging in soft pastel colours with traditional retro-style graphics. As far as the packaging style is concerned, thee respondents prefer a matt and porous material with a simple and comfortable shape. In case of the font typed on the packaging, the elderly expressed their preference as far its simplicity is concerned. Similarly, the preferred type of product packaging closure which arouses greater trust is a traditional one and easy in handling. The above observations may result from natural inclination of the elderly for greater conservatism and attachment to verified solutions and familiar themes.

\section{CONCLUSIONS}

The society ageing process forces the necessity to put attention to particular needs and expectations of the elderly consumers. It is necessary to identify the needs and expectations in the field of food product packaging. The distinguished needs constitute an opportunity for development of contemporary entrepreneurship by designing and offering innovative packaging which fulfil expectations of the elderly consumers.

Effectiveness of entrepreneurs' actions in new demographic conditionings will depend on quality and availability of their products for the elderly. The conducted research allowed to identify features of food product pack-aging which are important from the point of view of the elderly and to identify of unmet market needs that determine the opportunities and directions of entrepreneurship development. Such consumer segment puts particular attention to certain benefits from packaging, such as a guarantee of safe product consumption, ease of product storage as well as provision of a necessary scope of information by the packaging. Ease of carrying as well as an opportunity to use the packaging for different purposes turned out to be important benefits for the elderly consumers. Thus, offering products consistent with expectations related to packaging functionality and safety constitutes an opportunity for efficient building of a competitive advantage on the market. An ability to create and take actions adjusting products to growing needs and expectations of the elderly consumers as well as launching new commodities, which fulfil expectations of this 
consumer segment, will constitute an entrepreneurship test, especially for small and medium business entities.

The research also shows that the elderly consumers prefer concrete features in the range of visual aspect of food product packaging. Therefore, actions aiming at persuading and attaching consumers to a given product by means of communication of packaging constitute a chance for the entrepreneurship. Efficient reaching the elderly customer segment with a product offer creates an opportunity of taking numerous entrepreneurial actions using both traditional and modern marketing instruments and techniques.

To sum up the discussion, it can be stated that the food product market is one of the fastest developing economic sectors, in which the number of innovative products for the elderly consumers will continually grow. Not only will success of implemented innovations depend on their type but also on the level of satisfaction of consumer needs for such products. Following the silver economy concept, it should be emphasized that the customers of business entities offering products and services adjusted to the needs of the elderly constitute both the elder in person and their families, guardians and institutions looking after them.

\section{REFERENCES}

[1] Bonn Declaration for the Silver Economy as an Opportunity for Quality of Life, Economic Growth and Competitiveness in Europe, 2005, www.silvereconomy-europe.org (02.09.2016).

[2] Bossak J.W., Konkurencja i wspótpraca międzynarodowa, Difin, Warszawa 2013.

[3] Europe's demographic future. Facts and figures on challenges and opportunities, 2007, European Commission, Luxembourg.

[4] Glinka B., Gudkova S., Przedsiębiorczość, Wolters Kluwer, Warszawa 2011.

[5] Golinowska S., Srebrna gospodarka - element strategii rozwoju regionalnego [in:] Starzejace się spoteczeństwo: nowe zadania dla polityk publicznych, Małopolskie Studia Regionalne nr 2-3/31-32/2014, Kraków 2014.

[6] Graafmans J., Taipale V., Charness N., Gerontechnology. A sustainable investment in the future, IOS Press, Amsterdam 1998.

[7] Hoyer W.D., MacInnis D.J., Consumer behavior, Australia: South-Western Cengage Learning 2010.

[8] Kabaja B., Możliwości wykorzystania metody TVScore do oceny znakowania opakowań na przykładzie suplementów diety, Zeszyty Naukowe UEK 8(956), Kraków 2016.

[9] Kubejko-Polańska E., The role of local self-government in stimulating urban development in the context of the construction of age-friendly cities and the concept of Silver Economy, Nierówności Społeczne a Wzrost Gospodarczy, 2017, nr 49 (1/2017).

[10] Lisińska-Kuśnierz M., Food packaging as non-satisfactory comunication instrument in opinion of consumers [in:] Innovations in product development and packaging, UEK, Kraków 2016.

[11] Lockhart H.E., A Paradigm for Packaging, Packaging Technology and Science, 1997, 10(5).

[12] Mossakowska M., Więcek A., Błędowski P., Aspekty medyczne, psychologiczne, socjologiczne i ekonomiczne starzenia się ludzi w Polsce, Termedia Wydawnictwa Medyczne, Poznań 2012. 
[13] Rembiasz M., Srebrna gospodarka szansa rozwoju MSP, Zeszyty Naukowe Uniwersytetu Szczecińskiego nr 848, Ekonomiczne Problemy Usług nr 116, Szczecin 2015.

[14] Silver Economy Network of European Regions: SEN@ER (www.silvereconomyeurope.org).

[15] Szukalski P., Trzy kolory: srebrny. Co to takiego silver economy?, „Polityka Społeczna” 2012, nr 5-6.

[16] Szymczak J., Ankiel-Homa M., Opakowanie jednostkowe $w$ działaniach marketingowych przedsiębiorstw, Wydawnictwo Akademii Ekonomicznej w Poznaniu, Poznań 2007.

[17] Świda J., Cholewa-Wójcik A., Kawecka A., Determinants of Creating Packaging Innovations for Older Consumers, Proceedings of The International Business Conference 2016: Searching for Innovative and Creative Business Solutions, Vilniaus Kolegija/ University of Applied Sciences, Vilnius - Lithuania 2016.

[18] Świda J., An elderly consumer as a specific research object of the marketing research, Gębarowski M., Hermaniuk T. (ed.) Food Product Marketing. Concepts and Research. University of Maribor, Slovenia 2015.

[19] Świda J., Zachowania rynkowe starszych konsumentów z punktu widzenia projektowania warstwy wizualnej opakowań, Zeszyty Naukowe UEK (918), Kraków 2013.

[20] Yap C.W., Yazdanifard R., How Consumer Decision Making Process Differ From Youngster to Older Consumer Generation, "Journal of Research in Marketing” 2014, 2(2).

[21] Zalega T., Zachowania konsumenckie osób starszych w Polsce, „Handel Wewnętrzny” 2016, $\mathrm{nr} 2$.

[22] Założenia Długofalowej Polityki Senioralnej w Polsce na lata 2014-2020, 2013, Monitor Polski Dziennik Urzędowy Rzeczypospolitej Polskiej, Warszawa.

\section{SZANSE DLA ROZWOJU PRZEDSIEBIORCZOŚCI W ZAKRESIE DOSTOSOWANIA PRODUKTÓW DO POTRZEB OSÓB STARSZYCH}

Proces starzenia się społeczeństwa wymusza konieczność zwrócenia uwagi na specyficzne potrzeby i wymagania konsumentów w starszym wieku. Identyfikacja tychże potrzeb i wymagań jest niezbędna również w branży opakowań produktów spożywczych. Rozpoznane potrzeby stanowią bowiem szansę dla rozwoju współczesnej przedsiębiorczości poprzez projektowanie i oferowanie na rynku innowacyjnych opakowań spełniających oczekiwania starszych konsumentów. W prezentowanym artykule podjęto próbę zidentyfikowania możliwości rozwoju przedsiębiorczości w obszarze srebrnej gospodarki w zakresie dostosowania opakowań produktów spożywczych do potrzeb starszych konsumentów. Badania zostały przeprowadzone metodą wywiadu kwestionariuszowego CATI. Kwestionariusz ankietowy składał się z dwóch części. Pierwsza część zawierała pytania dotyczące identyfikacji potrzeb i oczekiwań starszych konsumentów w odniesieniu do opakowań produktów spożywczych. Drugą część kwestionariusza ankietowego stanowiły pytania opisujące respondentów. Przeprowadzone badania pozwoliły na identyfikację cech opakowań produktów spożywczych istotnych z punktu widzenia seniorów. Ten segment konsumentów zwraca szczególną uwagę na konkretne korzyści z opakowań, m.in.: gwarancję bezpieczeństwa spożycia produktu, łatwość przechowywania produktu oraz dostarczanie przez opakowanie niezbędnego zakresu informacji. Z badań wynika również, iż starsi konsumenci preferują konkretne cechy w zakresie warstwy wizualnej opakowań produktów spożywczych. Szansą dla rozwoju 
przedsiębiorczości mogą stać się zatem działania zmierzające do przekonania oraz przywiązania konsumentów do danego produktu wykorzystując komunikatywność opakowań.

Słowa kluczowe: starsi konsumenci, srebrna gospodarka, starzenie się społeczeństwa, opakowanie produktów spożywczych, badania konsumenckie.

DOI: $10.7862 /$ rz.2017.hss.60

Przestano do redakcji: kwiecień $2017 r$.

Przyjęto do druku: wrzesień 2017 r. 